\title{
ASPSCR1/TFE3 Fusion Gene
}

National Cancer Institute

\section{Source}

National Cancer Institute. ASPSCR1/TFE3 Fusion Gene. NCI Thesaurus. Code C99705.

A fusion gene that results from chromosomal translocation $t(X ; 17)(p 11.2 ; q 25)$ or $\operatorname{der}(X) t(X ; 17)(p 11 ; q 25)$ which fuses the 5 ' half of the ASPSCR1 gene to either exon 3 or 4

of the TFE gene. This fusion is associated with both alveolar soft part sarcoma and primary renal tumor. 